\title{
Narrative and Europeanization: bringing together two processual notions
}

\author{
Klarissa Lueg (klueg@sdu.dk) \\ University of Southern Denmark, Denmark \\ Sören Carlson (soeren.carlson@uni-flensburg.de) \\ Europa-Universität Flensburg, Germany
}

\section{State of the art - subjects and range within contemporary research}

Narratives and the notion of Europe are closely interconnected, both by cultural frameworks of what constitutes Europe and 'being European', and by EU-related stories crafted for political purposes. In a broader, much more paradigmatic perspective, narrative inquiry suggests that stories, as constructed and reconstructed by agents, are to be considered constituents of social interaction and phenomena, in general. Narratives construct and constrain individual and group identity (Hyvärinen et al., 2010; Loseke, 2007; Somers, 1994; Weick, 1995). What is more, they do construct phenomena agents perceive as reality (Bruner, 1991) by organizing identities into cultural or political institutions (Ewick \& Silbey, 1995). Through the use of narratives and stories humans create a sense of meaning and purpose between fragmented events and experiences. Experiences are meaningful parts of shaping humans' stories about themselves (Johansen, 2012; McAdams, 1996) with regard to the social context they relate to. In exactly this sense, narratives contribute to the construction of 'Europe' and its political representation, the European Union (EU), as meaningful entities, and they appear in various forms in relation to the process of European integration, thereby shaping and permeating countless dimensions of social life (for an overview of European narratives and counter-narratives cf. Bârğaoanu et al., 2017). This has been clearly demonstrated by an abundance of research literature coming from scientific disciplines such as anthropology, cultural studies, economics, geography, history, law, literary studies, political science and sociology (although the latter, we would argue, to date plays a somewhat minor role in this field). Thus, corresponding narratives have been crafted and construed, passed on and modified by various intellectuals, writers, artists, scholars and politicians (Chenal \& Snelders, 2012; Dittmer, 2014; Forchtner \& Kølvraa, 2012; Petrović, 2017) as well as by newspapers (Rovisco, 2010). Sometimes, this occurs in a professionally fabricated manner as in the case of the European Commission's attempt to foster a 'new narrative for Europe' (European Commission, 2014; cf. also Bouza García, 2017b; Kaiser, 2015, 2017), but it also takes place 'from below', that is, within the general population (Antonsich, 2008; Armbruster et al., 2003; Scalise, 2015). Equally, such narratives find their way into material objects such as films (Clemens, 2016), bank notes (Sassatelli, 2017), museums and exhibitions (Hilmar, 2016; Krankenhagen, 2011; Radonić, 2017; Van Weyenberg, 2019) as well as monuments and buildings (Perchoc, 2017). Narratives shape organizations (Lueg, 2018) and policies (e.g. Maricut, 2017) and constitute, more generally, the constructive pillars of Europe as a cultural and geographical entity in terms of belonging and not-belonging (Larsson \& Spielhaus, 2015; Tietze, 2013), as well as its borders (Andrén et al., 2017; Eder, 2006; Leontidou, 2004; Strüver, 2002). Furthermore, research has repeatedly pointed out (and criticized) how narratives provide sense to, 
sustain and justify - even if only temporarily and with varying success - the European Union as an institution and European integration as a political-economic project (Della Sala, 2016; Gilbert, 2008; Larat, 2005; Manners \& Murray, 2016; Mayer, 2019; Rosoux, 2017; Schünemann, 2017; Smismans, 2010). Finally, narratives play an important role in creating general representations of Europe, including its alleged (cultural) particularities, internal divisions and place in the world (D'Auria \& Vermeiren, 2018; Domnitz, 2010; Fornäs, 2017; Heller, 2006; Koschorke, 2013; Nicolaïdis \& Howse, 2002). Overall, narrative research on Europe, European integration and the EU thus abounds, uncovering narratives that range from 'small' stories to organizational narratives or various master - or 'grand' - narratives of what Europe is supposed to represent (see also Cloet, 2017; Franzius et al., 2019). On all levels, these stories contribute actively to the ongoing meaningful construction of 'Europe' as a social entity.

\section{A narrative approach to Europeanization: conceptual frame and motivation}

While some authors have already outlined the specific value of bringing narrative inquiry to the study of Europe and, in particular, of European integration and the EU (Ächtler, 2014; Bouza García, 2017a; Kaiser \& McMahon, 2017; Koschorke, 2019; Manners \& Murray, 2016), it is surprising to find that this strand of research only rarely, and without greater detail, links up with one of the most prominent concepts to be found in social science research on these issues, i.e. the notion of Europeanization. Most often, this concept is used - particularly within political science, economics and European studies - to refer to the various processes through which standards and directives, originating at EU level, are implemented at and adapted to the national level, as well as their wider effects on national economic and political structures (Olsen, 2002; Radaelli, 2003). Besides this dominant understanding, the term 'Europeanization' has also been employed more recently (especially within sociological work) to denote how societies change as a result of European integration and how, in turn, this process rests on specific socio-structural foundations and is affected by the European population itself, particularly with regard to the various forms of cross-border (inter-)actions and relations that have formed over the years (Favell \& Guiraudon, 2009; among others, see also Beck \& Grande, 2007; Carlson, 2020; Fligstein, 2008; Recchi et al., 2019). Given these understandings of Europeanization, its connection to the notion of narrative may seem obvious. However, except for Jones and Clark (2008), Krankenhagen (2011) and Trenz $(2015,2016)$, it is actually seldomly argued for and motivated as a theoretical and methodological perspective, including its epistemological logics: how does a narrative perspective on Europe help us understand social processes? Why is it appropriate to select a narrative perspective when we discuss Europe and agents invested in Europe as our object of inquiry?

Against this background, this special issue aims to make the case for combining both notions more explicitly in further research. In so doing, we argue, first of all, that a narrative perspective - that is, including stories of Europe as an object of inquiry as well as a method of research - is appropriate, because Europe, as a social construct, does relate to several similar parameters as narratives do: it is, in its core, a temporal, and processual, notion referring to continuous changes (Moumoutzis \& Zartaloudis, 2016; Salvatore et al., 2013), it is reliant on plots, and on citizen discourse as language-in-use (for an overview of stories of Europe in national contexts cf. Lacroix \& Nicolaïdis, 2010), and it needs agents to advance its storyline (Eder \& Carlson, 2020 in this issue).

Second, both Europeanization and narrative entail the notion of being an ongoing process, with various pathways to various endings being envisioned (Eder, 2009). In consequence, we suggest that 'Europe' can be called what Boje has termed an antenarrative - a fragmented story in the sense that it is a story in the making, a bet on how it could look like from a potential, retrospective look into the future (Boje, 2001a, 2008; Henderson \& Boje, 
2016). Europe has a (strategic) storyteller in the form of the EU, and there is also a decided recipient, that is, EU citizens and all those interested in European matters. However, there are many more actors and social groups involved in telling additional, sometimes alternative, parallel or counter-stories of Europe, as Gärtner (2020, in this issue) points out with her research on the story of 'paradise Europe' as told by Cameroonian migrants. The story of Europe, quite clearly, is hinged upon morale and a framing of the right thing to do - if political reasoning seems to lose acceptance (such as emphasizing the peace-keeping effect of having a strong economic union), common European values are conjured (Vidmar Horvat, 2012). Such 'EU values', equated with a 'European way of life' by the EU (European Commission, 2020), often lack definition but seem to cater to an essentialist understanding of what the cultural core of Europe is - leading to practices of othering as well as innerand outer-European exclusion, as shown in culturally biased questions by the Eurobarometer or by EU ads (Watt, 2012).

Third, Europe and the EU - both organizations from a perspective grounded in communication theory (Schoeneborn, 2011 for an elaboration on communication as constitutive for organizations) - shape meaning and provide sense-making on all levels of social observation, just like narrative itself. On the micro level, people in and relating to Europe tell stories of belonging or not-belonging, making sense of their own and others' identities. On the social meso level, researchers have examined various types of group processes and interactions ('group' implying communities and any type of organization). It is at the mesolevel of intersubjective organizing and organizations that institutionalized cultural narratives are being negotiated and transformed into policies, rules, laws and structures - a process that is embodied, nearly ideal typically, by Europe as a cultural tale and the EU as its structural institutionalization. Finally, on the macro level Europeanization can be understood as a changing force towards societal processes in larger interrelations and more general patterns, such as intra-European patterns of social class or structure, systems or the power of culture and religion. Europe, as a notion, impacts on all these levels, and all these levels can be researched by making use of narrative inquiry (Lueg et al., 2020, 7). To further stress our argument about the inherent connection between narrative and Europeanization and highlight the added value of the former for analyzing the latter, we lay bare several features and core notions of narrative as well as their interconceptual dynamics.

\section{What is narrative and what does it have to offer for Europeanization research?}

Narrative research vastly goes above and beyond the analysis of 'a story': narrative inquiry may focus on researching one precisely definable storyline but can also move far beyond this. Constructionist narrative research tends to refer to the basic definition of narrative merely to have a blueprint to deviate from. Such a definitory approach to narrative, however, helps to understand, and in consequence to deconstruct and extend, the elements that built it. A narrative is often described as 'having' the following characteristics: it has a temporal order, arranged along the elements beginning, middle and end. Also, the story has a "teller" (Ewick \& Silbey, 1995, 200), or, at least, one agent mediating the story as the "one who speaks" (Barthes \& Duisit, 1975, 261; emphasis in original) and a "recipient of narrative" (Barthes \& Duisit, 1975, 260). Third, the story 'has' emplotment: many episodes or sequences are connected to each other. A narrative, in sum, is often described as grasping together characters, plots, actions and events into a meaningful, coherent whole in a logical temporal order (Bal, 1997; Barthes \& Duisit, 1975; Kvernbekk, 2003), this grasping together being told by someone to someone else (for an overview see Pentland, 1999). 


\subsection{Morale, power structures, and narrative}

We emphasize, amongst all those features, the moral interpretation of a story (White, 1990) as being of vital relevance for social narrative inquiry. A narrative can represent powerful mental models that are being fought about socially. Stories entail propositions about what is 'the right thing to do', who is 'in the right' (see the notion of 'European values') and often these moral assessments provide subtle directions for social conduct in general, having implications beyond the plot at hand. Narratives, thus, are instruments, consciously or unconsciously, to produce a normatively laden social order (Frandsen et al., 2017; Giddens, 1991). Consequently, narratives do have the potential to reproduce or challenge "existing relations of power and inequity" (Ewick \& Silbey, 1995, 197). There are social rules for "when, what, how, and why stories are told" (Ewick \& Silbey, 1995, 197), and 'narrating' means relating to these rules, be it by being cooperative or by deviating from them. Understanding patterns of consistent social interpretations and representations of certain events as narratives, in consequence, is highly useful for being able to criticize power relations. Understanding narrative(s) means being able to answer the question of how social groups intersubjectively account for social life. One example of this is Lueg's (2018) study on how different groups of university members understand and appropriate the concept of Europeanization in relation to educational and organizational changes, leading to intra-organizational power struggles as a result. Another example would be Hilmar's (2016) analysis of the role of symbolic power in discussions of curators of the House of European History about the way to present European history to the public. Finally, one may think here of Nicolaïdis and Howse (2002) who engage with the issues of power and morale by pointing out how specific narratives serve to project 'Europe' (implying the EU) as a civilian power to the wider world and the implications deriving from this.

\subsection{Master narrative}

Though all narratives can be argued to imply a certain social morale, there are some narratives that are more durably successful at this than others. Such narratives that then serve as blueprints or guidelines for other stories are called master narratives (Bamberg \& Andrews, 2004, 360). Master narratives are those stories that are, at least to a certain point in time, autonomous from those agents they impact on. Czarniawska highlights this by stating that "[o]ther people or institutions sometimes concoct narratives for us, without including us in any conversation [...]" (Czarniawska, 1997, 14). A master narrative, in consequence, is a typical story with a normative appeal and it is one that has a certain level of autonomy from, and power over, the 'agents' involved in the very story (similar notions with each of their own, slightly different characteristics, however, would be 'cultural model', 'figured world' or 'discourse', for example; for an overview cf. Gee, 2009, 89). A master narrative can thus guide beliefs and cultural-social behavior of social groups, and it is entirely possible that these patterns of behavior are simply accepted as social institutions, internalized and remain unquestioned. A master narrative is one with or without resistance; resistance, however, is possible (McLean \& Syed, 2015, 323). In this vein, emphasizing morale and power, Lueg, Graf and Powell $(2020,272)$ propose these three features as applicable to a master narrative (viz. hegemonic narrative): they are "told in favor of those holding power over social matters relevant to that story, told by those agents who actually are in power or benefit from this power structure, and outlining moral rules (if subtly) that prevent and oppose the imagining of any other power structure". It has to be considered that such power concentration and use is not inherently negative and oppressive, just as a counter-narrative (see below) cannot automatically be considered a liberating and justified force. Europe, and more so the EU, could be argued to be representing such a master narrative: it does impact the lives of citizens and non-citizens, it is often perceived as being detached from individual agency and influence and it clearly 
permeates, and thereby shapes, inter alia, law, politics and educational systems. Another example for a master narrative in relation to Europe is outlined by Heller (2006), who suggests that there are specific master narratives, grounded in European culture, in relation to the notion of freedom.

\subsection{Counter-narrative}

Like master narratives, counter-narratives also suggest a certain morale and normativity. However, it is one that may temporarily hold less power in the field the story relates to than the master narrative. A counter-narrative does not necessarily oppose the master narrative; it may also slightly deviate from this, or merely relate to a storyline that is perceived as worthy to counter and relate to. "Counter-narratives only make sense in relation to something else, that which they are countering. The very name identifies it as a positional category, in tension with another category" (Bamberg \& Andrews, 2004, x). Counternarratives are instruments for sensemaking for agents who cannot identify with the narrative of the given context, often perceived as hegemonic (Lundholt et al., 2017). Counternarratives can oppose master narratives, but they can also counter another counter-narrative. They are always subject to social perceptions and assessments - in no case do they automatically represent objective and static power relations. The normativity underlying the notions of master narrative and counter-narrative entail a slippery slope for researchers operating with these notions: counter-narratives are more often than not being equated with liberating, creative forces rebelling against the oppressive 'systematic' force of the master narrative, obviously because counter-movements, their linguistics, discourses, their formation etc. are interesting and worthwhile phenomena to investigate. A vast body of research is dedicated to counter-narratives as being liberating tools for marginalized agents, thus coining this notion as the legitimate force of 'the little man'. However, counter-narratives can be hostile, and destabilizing, and they can very well be harnessed by powerful agents to be turned into master narratives. This has been pointed out by several recent studies focusing on how Eurosceptic and right-wing groups of actors engage in the construction of counter-narratives in order to yield political and symbolic power (Conrad et al., 2019; Petrović, 2019; Volk, 2019; see also Lucchesi, 2020 in this issue).

\subsection{Antenarrative}

Between, and alongside, such master narrative/counter-narrative dynamics lies a narrative status that has been termed 'antenarrative': as mentioned before, an antenarrative is a notion that is supposed to grasp the concept of communicative acts that are not yet a fully developed story. Rather, they are an imagination of the future (Henderson \& Boje, 2016) or a story in the making, where narrators and other story stakeholders hope for, presently uncertain, outcomes of this story (Boje, 2001b; Lueg et al., 2019). Europe, and more so Europeanization, is an antenarrative in that it clearly envisions a specific ending of the story (whether this entails a tragic or happy ending, however, is highly contested and depends on the narrative structure of the specific story told; cf. Eder, 2009; Forchtner \& Eder, 2017), and it does employ features of narrative in order to engage citizens. However, it is not clear how this narrative, culturally and politically, will play out. The uncertainty of the storyline and the visibility of competing forces trying to impact on the storyline (e.g., European counter-movements) make Europeanization a storyline with potentially numerous endings. 


\section{Narrative inquiry into Europeanization: this issue}

The six contributions to this special issue, coming from various scientific disciplines, all aim to contribute further to our understanding of European integration and Europeanization processes from a narrative perspective. They do so by drawing on insights coming from narrative theory and/or by shining a light on empirical instances of narrative constructions regarding 'Europe'. Along these lines, Antoinette Fage-Butler and Katja Gorbahn (2020) start with their empirical study Europeanness in Aarhus 2017's programme of events: identity constructions and narratives in which they focus on the meaning of 'Europeanness' as manifested in the events and storytelling of EU culture events. Their analysis draws on the case of Aarhus, the 'European Capital of Culture' in 2017, which is a title awarded annually to one city taking part in a designated competition within the European Union. This title, and the corresponding program, are installed with the purpose of fostering citizen approval and identification, as one of many examples for EU cultural initiatives. A 'Capital of Culture', by mandatory rule, has to include a 'European dimension' in its event program. However, interpretation of what this might entail, is left to the program hosts. Against this background, Fage-Butler and Gorbahn analyze Aarhus' program of events, employing Foucauldian discourse analysis to identify two main identity narratives: competing in the program were narratives of a) a "categorical identity discourse", constructing identity as homogenous and different from "the other", and b) a "relational identity", where identity is constructed as a dynamic network. By combining the various perspectives, the authors conclude that the construction of Europeanness could seem arbitrary, contradictory and sometimes muted to event attenders, thus pointing out the problems connected with such top-down installed narratives.

Next, Dario Lucchesi (2020), in his research article The refugee crisis and the delegitimization of the EU: a critical discourse analysis of newspapers' and users' narratives in Italian Facebook pages, provides insights into his study of social media discourse (here: Facebook) ensuing between newspaper article postings and user comments. In particular, Lucchesi focuses on social media narratives of Italy as a nation state versus Europe during the socalled EU refugee crisis between 2016 and 2018. His analysis finds that both newspapers and users, in their core storylines, shared a perception of a general cleavage between national and EU interests. Though not necessarily negative or defensive towards the EU, newspaper stories reconfirmed this basic dichotomy. Anti-immigrant and anti-EU comments ensued regardless of the normative perspective brought up by the newspaper report itself. Lucchesi argues that this is a recontextualization of discourses and finds the 'crisis'-related sentiments of being anti-EU and anti-refugee as essentially embedded in an old historical model of the nation state vs. transnationalism.

Iulia Patrut (2020), in her article Reciprocal reinforcement of entangled narrations on outer and inner European borders. Romanies, nation states and Europe, analyses the narration Die grosse schwarze Achse by author Herta Müller against the backdrop of European history behind the Iron curtain. In particular, she focuses on liminal figures, in particular the Romani, and the narrative strategy of "liminal view". Her article provides general considerations on what literary and journalistic narratives contribute to the construction of European borders (both outer- and inner-European borders). She also describes practices of inclusion and exclusion fostered by a European space conceived of as being homogenous. She argues that European border regions are predestined to function as settings for reflections on border regimes. Literature, she emphasizes, has largely contributed to questioning the interdependencies between cultural borders on the one hand and political borders on the other hand: thoughts on Europe and Europeanization, in literature writings, can be considered an archive of such perspectives over time. The narration Die grosse schwarze Achse is portrayed by Patrut as being situated in the context of opposition towards censorship and totalitarianism. Patrut emphasizes the "liminal figure", especially that of the 
so-called "Gypsie" as part of the narration. A typology of this and other liminal figures in the texts by Herta Müller is brought together with the suggestion that the characters' potential for resistance hinges on their liminal status. In sum, Patrut lines out how the narration by Herta Müller, in general, and the highlighting of lives and living conditions of Romanis as "Gypsies", in particular, outline vital European narratives of borders, belonging and not-belonging, and the tensions between those narratives. Similar to Van der Waal (2019), Patrut's analysis thus alerts us to how such liminal and more vulnerable groups of people within the EU play an important role in the construction of 'Europe'.

The next article, Visualisation of the 'Balkan road': media representations of the refugee crisis at the periphery of Europe by Ksenija Vidmar Horvat (2020), also focuses on narratives as artistic products, albeit mediated by journalistic outlets. She observes and analyses visual representations, published in Slovenian news outlets, pertaining to narratives of Europe and Europeanization. These visual representations are selected from two cases: Vidmar Horvat collects and analyses her data from a newspaper series, including artistic drawings, and one single photograph that has garnered attention. She argues that these visual representations deviate from a conventional, rather stereotyped and othering view on the subject of visual representations, namely refugees. Overall, the investigation is set in the context of the so-called 'refugee crisis' of 2015, more precisely, in the national context of Slovenian media discourses and politics. The two cases of visual representations are analysed as counter-narratives that struggle for legitimacy in view of hegemonic narratives. Such hegemonic narratives are in this case framed by historical stories, as induced by Western discourse. Local counter-narratives, as represented in the visual art pieces, may help in advancing the European project.

Marlene Gärtner (2020) then contributes an empirical study of how narratives and the perceived 'crisis' of migration from the Global South are interrelated. She contributes the text Narrating migration in terms of the Global North: Institutional attempts to counter the "Paradise Europe" narrative in Cameroon. The focus of her analysis are EU awareness campaigns in Cameroon, meant to discourage migration. These campaigns, Gärtner shows, are focused on invalidating a rose-colored dream of Europe. She identifies two main narratives running parallel to each other. First, there is the "Paradise Europe" narrative she discovers in interviews with Cameroonians. This narrative is the imagination of immediate success abroad and a crucial factor for migration to Europe. Second, there is the "You can be happy at home" narrative as launched by EU member states, an institutional counter-narrative, failing however, in telling a valid counter-story. Gärtner finds deterring campaigns by EU member states "naïve" in face of the powerful narratives of migration, success and an adventurous road to success. The misbelief that the mediation of "facts" and "information" can counter a "guiding dream of Europe" dooms the campaigns to fail and shows, at the same time, European self-righteousness with a view to North-South power relations.

Finally, the contribution Europe as a narrative laboratory. Klaus Eder on European identity, populist stories and the acid bath of irony by Klaus Eder and Sören Carlson (Eder \& Carlson, 2020) gives an overview of essential propositions in Eder's work on Europe, identity and narrative. The authors summarize Eder's sociological approach to a European identity, seen as emerging by means of narrative processes, and, based on that, then engage in a conversation about central propositions arising from this work. Thus, they discuss, inter alia, the concepts of narrative resonance and isomorphism, the relation between narrative and network structures, and they touch upon the (neglected) role of narratives in socialscientific thinking, thereby taking up many of the issues addressed in this special issue. In addition to the papers selected for this themed issue, we are glad to be able to include Niels Exner's A century with and against the market. The ILO and 'global social justice', which reviews Daniel Maul's research monograph The International Labour Organization. 100 Years of Global Social Policy, and Georg Vobruba's reflection on the basic income 
debate, entitled The way out of Basic Income's utopia trap. Making sense of the basic income debate. We thank Christian Möstl and Karl-Julian Zapff for their help in carefully compiling and prestructuring the extensive research literature that we draw on in this article. Furthermore, we would like to thank CPE's editorial team for their generous support in the production process of this special issue.

\section{References}

Ächtler, N. (2014). Was ist ein Narrativ? Begriffsgeschichtliche Überlegungen anlässlich der aktuellen Europa-Debatte. KulturPoetik, 14(2), 244-268.

Andrén, M., Lindkvist, T., Söhrman, I., \& Vajta, K. (Eds.) (2017). Cultural borders of Europe. Narratives, concepts and practices in the present and the past. New York:

Berghahn.

Antonsich, M. (2008). The narration of Europe in 'national' and 'post-national' terms: gauging the gap between normative discourses and people's views. European Journal of Social Theory, 11(4), 505-522.

Armbruster, H., Rollo, C., \& Meinhof, U.H. (2003). Imagining Europe: everyday narratives in European border communities. Journal of Ethnic and Migration Studies, 29(5), 885899.

Bal, M. (1997). Narratology: introduction to the theory of narrative (2. ed.). Toronto: University of Toronto Press.

Bamberg, M., \& Andrews, M. (2004). Considering counter-narratives: narrating, resisting, making sense. Amsterdam: John Benjamins.

Bârğaoanu, A., Buturoiu, R., \& Radu, L. (2017). Why Europe? Narratives and counter-narratives of European integration. Frankfurt am Main: Peter Lang.

Barthes, R., \& Duisit, L. (1975). An introduction to the structural analysis of narrative. New Literary History, 6(2), 237-272.

Beck, U., \& Grande, E. (2007). Cosmopolitan Europe. Cambridge: Polity.

Boje, D. M. (2001a). Narrative methods for organizational and communication research (1 ed.). London: Sage.

Boje, D. M. (2001b). What is antenarrative. Retrieved from https://business.nmsu.edu/ dboje/papers/what_is_antenarrative.htm.

Boje, D. M. (2008). Storytelling organizations. Thousand Oaks: Sage.

Bouza García, L. (2017a). Introduction: a narrative turn in European studies. Journal of Contemporary European Studies, 25(3), 285-290.

Bouza García, L. (2017b). The 'New Narrative Project' and the politicisation of the EU. Journal of Contemporary European Studies, 25(3), 340-353. 
Bruner, J. (1991). The narrative construction of reality. Critical Inquiry, 18(1), 1-21.

Carlson, S. (2020). Transnationale Karrieren und europäische Vergesellschaftung. Zur (Im-)Mobilität junger, hochqualifizierter deutscher Berufstätiger. Bielefeld: Transcript.

Chenal, O., \& Snelders, B. (Eds.) (2012). Remappings. The making of European narratives. Amsterdam: European Cultural Foundation.

Clemens, G. (2016). „Von der Venus von Milo bis zu Jean Monnet“ - Narrative der europäischen Integration. In G. Clemens. (Ed.), Werben für Europa. Die mediale Konstruktion europäischer Identität durch Europafilme (401-438). Paderborn: Ferdinand Schöningh.

Cloet, Q. (2017). Two sides to every story(teller): competition, continuity and change in narratives of European integration. Journal of Contemporary European Studies, 25(3), 291-306.

Conrad, M., Hallgrímsdóttir, H.K., \& Brunet-Jailly, E. (2019). The heroes and villains of an alternative Europe - how EU contestation shapes narratives of Europe in Germany. Politique Européenne, 66(4), 96-119.

Czarniawska, B. (1997). Narrating the organization: dramas of institutional identity. Chicago: University of Chicago Press.

D’Auria, M., \& Vermeiren, J. (Eds.) (2018). Narrating Europe: conceptions of European history and identity in historiography and intellectual thought. History. The Journal of the Historical Association, 103(356), 381-519.

Della Sala, V. (2016) Europe's odyssey? Political myth and the European Union. Nations and Nationalism, 22(3), 524-541.

Dittmer, J. (2014). Towards new (graphic) narratives of Europe. International Journal of Cultural Policy, 20(2), 119-138.

Domnitz, C. (2010). Kommt europäische Kultur aus dem Osten? Die EU-Osterweiterung beförderte essenzielle Narrative eines kulturellen Europas. In J. Wienand \& C. Wienand (Eds.), Die kulturelle Integration Europas (255-275). Wiesbaden: Springer VS.

Eder, K. (2006). Europe's borders: the narrative construction of the boundaries of Europe. European Journal of Social Theory, 9(2), 255-271.

Eder, K. (2009). A theory of collective identity: making sense of the debate on a "European identity". European Journal of Social Theory, 12(4), 427-447.

Eder, K., \& Carlson, S. (2020). Europe as a narrative laboratory. Klaus Eder on European identity, populist stories, and the acid bath of irony. Culture, Practice \& Europeanization, 5(1), 102-116.

European Commission. (2014). New narrative for Europe: The mind and body of Europe. Last accessed: August 5, 2020. Retrieved from http://ec.europa.eu/culture/policy/newnarrative/documents/declaration_en.pdf. 
European Commission. (2020). The EU values. Retrieved from https://ec.europa.eu/component-library/eu/about/eu-values/.

Ewick, P., \& Silbey, S.S. (1995). Subversive stories and hegemonic tales: toward a sociology of narrative. Law \& Society Review, 29(2), 197-226.

Fage-Butler, A., \& Gorbahn, K. (2020). Europeanness in Aarhus 2017's programme of events: identity constructions and narratives. Culture, Practice \& Europeanization, 5(1), 16-33.

Favell, A., \& Guiraudon, V. (2009). The sociology of the European Union: an agenda. European Union Politics, 10(4), 550-576.

Fligstein, N. (2008). Euroclash. The EU, European identity, and the future of Europe. Oxford: Oxford University Press.

Forchtner, B., \& Eder, K. (2017). Europa erzählen: Strukturen europäischer Identität. In G. Hentges, K. Nottbohm, \& H.-W. Platzer (Eds.), Europäische Identität in der Krise? Europäische Identitätsforschung und Rechtspopulismusforschung im Dialog (79-100). Wiesbaden: Springer VS.

Forchtner, B., \& Kølvraa, C. (2012). Narrating a 'new Europe': From 'bitter past' to selfrighteousness? Discourse \& Society, 23(4), 377-400.

Fornäs, J. (Ed.) (2017). Europe faces Europe: narratives from its Eastern half. Bristol: Intellect Books.

Frandsen, S., Kuhn, T., \& Lundholt, M. W. (2017). Counter-narratives and organization (Vol. 39). Abingdon: Routledge.

Franzius, C., Mayer, F.C., \& Neyer, J. (Eds.) (2019). Die Neuerfindung Europas. Bedeutung und Gehalte von Narrativen für die europäische Integration. Baden-Baden: Nomos.

Gärtner, M. (2020). Narrating migration in terms of the Global North: institutional attempts to counter the "Paradise Europe" narrative in Cameroon. Culture, Practice \& Europeanization, 5(1), 85-101.

Gee, J. P. (2009). An introduction to discourse analysis: theory and method (2. ed.). Abdingdon: Routledge.

Giddens, A. (1991). Modernity and self-identity: self and society in the late modern age. Cambridge: Polity.

Gilbert, M. (2008). Narrating the process: questioning the progressive story of European integration. JCMS: Journal of Common Market Studies, 46(3), 641-662.

Heller, A. (2006). European master narratives about freedom. In G. Delanty (Ed.), Handbook of contemporary European social theory (257-265). Abingdon: Routledge.

Henderson, T. L., \& Boje, D. M. (2016). Organizational development and change theory: managing fractal organizing processes (Vol. 11). Abingdon: Routledge. 
Hilmar, T. (2016). Narrating unity at the European Union's new history museum: a cultural-process approach to the study of collective memory. European Journal of Sociology, 57(2), 297-329.

Hyvärinen, M., Hydén, L.-C., Saarenheimo, M., \& Tamboukou, M. (2010). Beyond narrative coherence: an introduction. In M. Hyvärinen, L.-C. Hydén, M. Saarenheimo, \& M. Tamboukou (Eds.), Beyond narrative coherence (1-15). Amsterdam: John Benjamins.

Johansen, T. S. (2012). The narrated organization: implications of a narrative corporate identity vocabulary for strategic self-storying. International Journal of Strategic Communication, 6(3), 232-245.

Jones, A., \& Clark, J. (2008). Europeanisation and discourse building: the European Commission, European narratives and European neighbourhood policy. Geopolitics, 13(3), 545-571.

Kaiser, W. (2015). Clash of cultures: two milieus in the European Union's 'A new narrative for Europe' project. Journal of Contemporary European Studies, 23(3), 364-377.

Kaiser, W. (2017). One narrative or several? Politics, cultural elites, and citizens in constructing a 'New narrative for Europe'. National Identities, 19(2), 215-230.

Kaiser, W., \& McMahon, R. (2017). Narrating European integration: transnational actors and stories. National Identities, 19(2), 149-160.

Koschorke, A. (2013). „Säkularisierung“ und „Wiederkehr der Religion“. Zu zwei Narrativen der europäischen Moderne. In U. Willems, Pollack, D., Basu, H., Gutmann, T., \& Spohn, U. (Eds.): Moderne und Religion: Kontroversen um Modernität und Säkularisierung (237-260). Bielefeld: Transcript.

Koschorke, A. (2019). Auf der Suche nach dem verlorenen Europa-Narrativ. In C. Franzius, F.C. Mayer, \& J. Neyer (eds.), Die Neuerfindung Europas. Bedeutung und Gehalte von Narrativen für die europäische Integration (21-32). Baden-Baden: Nomos.

Krankenhagen, S. (2011). Exhibiting Europe: the development of European narratives in museums, collections, and exhibitions. Culture Unbound, 3(3),269-278.

Kvernbekk, T. (2003). On identifying narratives. Studies in Philosophy and Education, 22(3), 267-279.

Lacroix, J., \& Nicolaïdis, K. (2010). European stories: intellectual debates on Europe in national contexts. Oxford: Oxford University Press.

Larat, F. (2005). Present-ing the past: political narratives on European history and the justification of EU integration. German Law Journal, 6(2), 273-290.

Larsson, G., Spielhaus, R. (2015). Narratives of inclusion and exclusion: Islam and Muslims as a subject of European studies. Journal of Muslims in Europe, 2(2), 105-113.

Leontidou, L. (2004). The boundaries of Europe: deconstructing three regional narratives. Identities. Global Studies in Culture and Power, 11(4), 593-617. 
Loseke, D. R. (2007). The study of identity as cultural, institutional, organizational, and personal narratives: theoretical and empirical integrations. The Sociological Quarterly, 48(4), 661-688.

Lucchesi, D. (2020). The refugee crisis and the delegitimisation of the EU: a critical discourse analysis of newspapers' and users' narratives in Italian Facebook pages. Culture, Practice \& Europeanization, 5(1), 34-51.

Lueg, K. (2018). Organizational changes towards a European academic field. A case study of frictions in the narratives of Europeanization at a German university from an institutional perspective. Innovation: The European Journal of Social Science Research, 31(4), 484-503.

Lueg, K., Bager, A., \& Lundholt, M.W. (2020): What counter- narratives are. Dimensions and levels of a theory of middle range. In K. Lueg \& M.W. Lundholt (Eds.), The Routledge handbook of counter-narratives (1-14). Abingdon: Routledge.

Lueg, K., Boje, D., Lundholt, M.W., \& Graf, A. (2019). How an organizational narrative creates a new doxa in higher education: A case study of sociomaterial construction of educational value in a Danish university. Paper presented at the 35th EGOS Colloquium, Edinburgh, United Kingdom.

Lueg, K., Graf, A., \& Powell, J.W. (2020). Hegemonic university tales. Discussing narrative positioning within the academic field between Humboldtian and managerial governance. In K. Lueg \& M.W. Lundholt (Eds.), The Routledge handbook of counter-narratives (269282). Abingdon: Routledge.

Lundholt, M.W., Maagaard, C.A., \& Piekut, A. (2017). Counter-narratives. International Encyclopedia of Strategic Communication. Wiley-Blackwell.

Manners, I., \& Murray, P. (2016). The end of a noble narrative? European integration narratives after the Nobel Peace Prize. JCMS: Journal of Common Market Studies, 54(1), 185202.

Maricut, A. (2017). Different narratives, one area without internal frontiers: why EU institutions cannot agree on the refugee crisis. National Identities, 19(2), 161-177.

Mayer, F.C. (2019). Die Europäische Union als Rechtsgemeinschaft - ein überholtes Narrativ? In C. Franzius, F.C. Mayer, \& J. Neyer (Eds.), Die Neuerfindung Europas. Bedeutung und Gehalte von Narrativen für die europäische Integration (111-130). Baden-Baden: Nomos.

McAdams, D. P. (1996). Personality, modernity, and the storied self: a contemporary framework for studying persons. Psychological Inquiry, 7(4), 295-321.

McLean, K.C., \& Syed, M. (2015). Personal, master, and alternative narratives: an integrative framework for understanding identity development in context. Human Development, 58(6), 318-349. 
Moumoutzis, K., \& Zartaloudis, S. (2016). Europeanization mechanisms and process tracing: a template for empirical research.JCMS: Journal of Common Market Studies, 54(2), 337-352.

Nicolaïdis, K., \& Howse, R. (2002). 'This is my EUtopia ...': narrative as power. JCMS: Journal of Common Market Studies, 40(4), 767-792.

Olsen, J.P. (2002). The many faces of Europeanization. JCMS: Journal of Common Market Studies, 40(5), 921-952.

Patrut, I. (2020). Reciprocal reinforcement of entangled narrations on outer and inner European borders. Romanies, nation states and Europe. Culture, Practice \& Europeanization, 5(1), 52-66.

Pentland, B.T. (1999). Building process theory with narrative: from description to explanation. The Academy of Management Review, 24(4), 711-724.

Perchoc, P. (2017). Brussels: what European urban narrative? Journal of Contemporary European Studies, 25(3), 367-379.

Petrović, N. (2017). The Promethean role of Europe: changing narratives of the political and scholarly left. National Identities, 19(2), 179-197.

Petrović, N. (2019). Divided national memories and EU crises: how Eurosceptic parties mobilize historical narratives. Innovation: The European Journal of Social Science Research, 32(3), 363-384.

Radaelli, C.M. (2003). The Europeanization of public policy. In K. Featherstone \& C.M. Radaelli (eds.), The Politics of Europeanization (27-56). Oxford: Oxford University Press.

Radonić, L. (2017). Post-communist invocation of Europe: memorial museums' narratives and the Europeanization of memory. National Identities, 19(2), 269-288.

Recchi, E., Favell, A., Apaydin, F., Barbulescu, R., Braun, M., Ciornei, I., Cunningham, N., Díez Medrano, J., Duru, D.N., Hanquinet, L., Pötzschke, S., Reimer, S.D., Salamońska, J., Savage, M., Jensen, J.S., \& Varela, A. (2019). Everyday Europe. Social transnationalism in an unsettled continent. Bristol: Policy.

Rosoux, V. (2017). Reconciliation narrative: scope and limits of the Pax Europeana. Journal of Contemporary European Studies, 25(3), 325-339.

Rovisco, M. (2010). One Europe or several Europes? The cultural logic of narratives of Europe - views from France and Britain. Social Science Information, 49(2), 241-266.

Salvatore, A., Schmidtke, O., \& Trenz, H.-J. (2013). Rethinking the public sphere through transnationalizing processes: Europe and beyond. Basingstoke: Palgrave Macmillan.

Sassatelli, M. (2017). 'Europe in your Pocket': narratives of identity in euro iconography. Journal of Contemporary European Studies, 25(3), 354-366. 
Scalise, G. (2015). The narrative construction of European identity. Meanings of Europe 'from below'. European Societies, 17(4), 593-614.

Schoeneborn, D. (2011). Organization as communication: a Luhmannian perspective. Management Communication Quarterly, 25(4), 663-689.

Schünemann, W.J. (2017). Almost the same stories: narrative patterns in EU treaty referendums. National Identities, 19(2), 199-214.

Smismans, S. (2010). The European Union's fundamental rights myth. JCMS: Journal of Common Market Studies, 48(1), 45-66.

Somers, M. (1994). The narrative constitution of identity: a relational and network approach. Theory and Society, 23(5), 605-649.

Strüver, A. (2002). Significant insignificance - boundaries in a borderless European Union: deconstructing the Dutch-German transnational labor market. Journal of Borderlands Studies, 17(1), 21-36.

Tietze, N. (2013 ). Imaginierte Gemeinschaft. Zugehörigkeiten und Kritik in der europäischen Einwanderungsgesellschaft. Hamburg: Hamburger Edition.

Trenz, H.-J. (2016). Narrating European society. Toward a sociology of European integration. Lanham. Lexington.

Trenz, H.-J. (2015). The saga of Europeanisation: on the narrative construction of a European society. In S. Börner \& M. Eigmüller (Eds.), European integration, processes of change and the national experience (207-227). Basingstoke: Palgrave Macmillan.

Van der Waal, M. (2019). The social imaginary of precarious Europeans: the cultural representation of European socio-economic precarity in 'Tascha' and 'Bande de Filles'. Politique Européenne, 66(4), 170-193.

Van Weyenberg, A. (2019). "Europe" on display: a postcolonial reading of the House of European History. Politique Européenne, 66(4), 44-71.

Vidmar Horvat, K. (2012). The predicament of intercultural dialogue: reconsidering the politics of culture and identity in the EU. Cultural Sociology, 6(1), 27-44.

Vidmar Horvat, K. (2020). Visualisation of the "Balkan road": media representations of the refugee crisis at the periphery of Europe. Culture, Practice \& Europeanization, 5(1), 67-84.

Volk, S. (2019). Speaking for "the European people"? How the transnational alliance Fortress Europe constructs a populist counter-narrative to European integration. Politique Européenne, 66(4), 120-149.

Watt, N. (2012). European commission criticised for 'racist' ad. The Guardian. Retrieved from https://www.theguardian.com/world/2012/mar/06/european-commission-criticised-racist-ad 
Weick, K. E. (1995). Sensemaking in organizations. London: Sage.

White, H. (1990). The content of the form: narrative discourse and historical representation. Baltimore: John Hopkins University Press. 